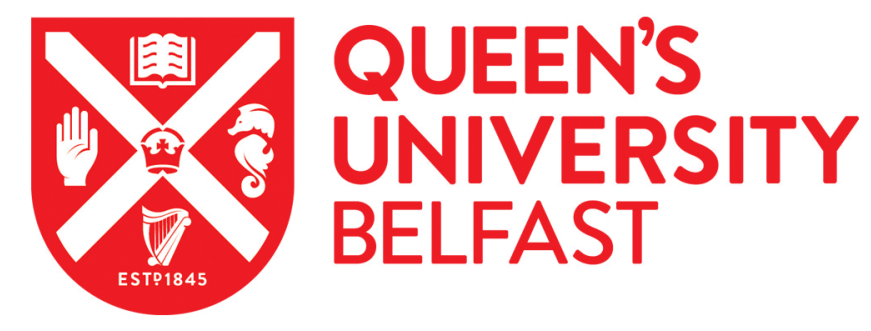

\title{
Big Society as Big Government: Cameron's Governmentality Agenda
}

Bulley, D., \& Sokhi-Bulley, B. (2014). Big Society as Big Government: Cameron's Governmentality Agenda. British Journal of Politics and International Relations, 16(13), 452-470. https://doi.org/10.1111/j.1467856X.2012.00547.x

Published in:

British Journal of Politics and International Relations

\section{Document Version:}

Peer reviewed version

\section{Queen's University Belfast - Research Portal:}

Link to publication record in Queen's University Belfast Research Portal

\section{Publisher rights}

(C) 2012 The Authors. British Journal of Politics and International Relations ( 2012 Political Studies Association.

This is the peer reviewed version of the following article: Bulley, D. and Sokhi-Bulley, B. (2014), Big Society as Big Government: Cameron's Governmentality Agenda. The British Journal of Politics \& International Relations, 16: 452-470, which has been published in final form at doi: 10.1111/j.1467-856X.2012.00547.x. This article may be used for non-commercial purposes in accordance with Wiley Terms and Conditions for Self-Archiving.

\section{General rights}

Copyright for the publications made accessible via the Queen's University Belfast Research Portal is retained by the author(s) and / or other copyright owners and it is a condition of accessing these publications that users recognise and abide by the legal requirements associated with these rights.

\section{Take down policy}

The Research Portal is Queen's institutional repository that provides access to Queen's research output. Every effort has been made to ensure that content in the Research Portal does not infringe any person's rights, or applicable UK laws. If you discover content in the Research Portal that you believe breaches copyright or violates any law, please contact openaccess@qub.ac.uk. 
The slogan that advertised the flagship policy of the Conservative Party in the 2010 general election read 'Big Society not Big Government’(Conservative Party, 2010a). Prime Minister Cameron (2011a) has asserted that the Big Society is his 'absolute passion ... it is a different way of governing, a different way of trying to change our country for the better'. The different way of governing is, as per the Conservative Party's slogan, not through big government. Deputy Prime Minister Nick Clegg (2010a), in an effort to assure us of the value of Cameron's big idea, goes further and equates 'Big Society' with 'liberalism', and simultaneously, 'empowerment' with 'responsibility'. The latter is key to the Big Society idea: Cameron claims to empower, that is to make us responsible as individuals, communities and, ultimately, as a population, so that we might become actively involved in community control and self-management. The Big Society aims to be a 'big advance for people power' (Cameron, 2010d) that will mend our currently ‘broken’ society (Cameron, 2009b).

This article argues that presenting the Big Society as a departure from big government is inaccurate and problematic. The aim of the article is to show that the Big Society in fact is big government, where we understand government as governmentality. That is, we argue that the Big Society is part of a modern form of managing the conduct of individuals and communities such that government, far from being removed or reduced, is bettered. To illustrate this, we look at two major Big Society initiatives and examine how they ultimately work to produce bigger, better, more efficient government: these are, first, the National Citizen Service (NCS) and second, the Community Resilience programme. The NCS refers to a nationwide initiative to recruit teenagers for a summer of activities in the hope of producing 'socially responsible' young people who can serve their community and get on with people from different backgrounds (Cameron, 2009b). The Community Resilience programme attaches itself to existing attempts to help communities better manage themselves in the face of emergencies and threats to their security, such as floods and terrorist attacks. In both examples, we examine how individual and group identities are regulated such that membership of (the big) society becomes conditional on certain forms of behaviour - and this regulation of behaviour is in fact big government(ality). ${ }^{1}$ Furthermore, the move to recognising the Big Society as governmentality is important because it reveals the way forms of management and control are being presented as precisely their opposite: freedom and

\footnotetext{
${ }^{1}$ We interpret 'government' (as used in the phrase 'big society as not big government') in the Foucualdian sense to be always, already governmentality - that is, a power relation of governing conduct - hence the use of government(ality).
} 
empowerment. Most current critiques of the Big Society are limited since they largely focus on the issue of veiled spending cuts. While we agree that the Big Society has acted as a mask for austerity measures, there is more to say. Moreover, to stop here would imply that increased or unchanged spending would make the Big Society benign. We thus focus on the 'more', arguing that regardless of spending cuts, the Big Society is disingenuous because it is, contrary to Cameron's marketing of it, about more control and the increased management of the behaviour of communities and individuals - i.e. bigger and better government.

Our reading of governmentality draws on the work of Michel Foucault and as such describes both a process and a methodology. As a process, governmentality challenges traditional understandings of 'government':

\footnotetext{
“Government” did not refer only to political structures or to the management of states; rather, it designated the way in which the conduct of individuals or of groups might be directed - the government of children, of souls, of communities, of the sick ... To govern, in this sense, is to control the possible field of action of others (Foucault, 2002, p. 341 - emphasis added).
}

Drawing on the centrality of 'conduct', Colin Gordon (1991, p. 2) has famously and succinctly described governmentality as 'the conduct of conduct' - that is, a form of activity or practice that aims to shape, guide or affect the conduct of some person or persons. It is essentially focused on tactics and techniques - the activities or processes of governing. As a methodology, governmentality refers to a way of thinking about the practice of government: 'who can govern; what governing is; what or who is governed' (Gordon, 1991, p. 3). It is a 'govern/mentality' (Barron, 2005, p. 984). It is thus a useful and creative tool for understanding the practices and processes of the Big Society. However, as a first step we must look at the way in which the Big Society has been outlined in its own terms.

\section{THE BIG SOCIETY}

No idea has caused quite as much derision or suspicion in recent years of British politics as Cameron’s 'Big Society’. Indeed, the government minister Tim Loughton publicly admitted in 2010 that 'most people' do not know what the phrase means, 'let alone the unfortunate 
ministers who have to articulate it' (quoted in Stratton, 2010). The academic community has been equally baffled (see Smith, 2010, p. 829), sometimes opting for the dismissal of the concept as both 'anaemic rhetoric' and an 'inverted form' of recycled Thatcherism (See Kerr, Byrne and Foster, 2011, pp. 196 and 198). This section will try to make sense of the Big Society by reconstructing it from the broad outline offered throughout Cameron's speeches and Conservative policy documents. We focus on Cameron's speeches because he has so heavily associated himself with the concept as his 'great passion' (Cameron, 2010d) and 'guiding philosophy' (Cameron, 2010a). Meanwhile, members of his government have not always been so supportive. His coalition partner and Deputy Prime Minister, Nick Clegg (2010b, p. 1), has claimed Big Society is just another name for Liberalism. More importantly, the Chancellor George Osborne (e.g. 2009a, 2009b and 2010) has - while repeating many of its themes such as social responsibility, the localisation of power, the brokenness of society, and the importance of the voluntary sector - resolutely avoided using the term 'Big Society'. Nonetheless, in 2012 Cameron continues to promote the idea (2012a) and launch new initiatives, such as Big Society Capital (2012b). ${ }^{2}$

While the exact phrase was first used in November 2009, Cameron was largely accurate to claim in 2010 that the argument behind the 'Big Society' has 'informed my whole time as Conservative leader'. ${ }^{3}$ The need for a stronger, more responsible society is founded on a diagnosis of Britain's problems based in the work of Iain Duncan Smith's Centre for Social Justice and its Social Justice Policy Group (see especially its Breakdown Britain report, 2006). This is used to back up the frequently repeated claim that Britain is a 'broken society' - thus the 'long term mission' of the Conservative government is to 'repair' (Cameron, 2008) or 'mend' our broken society (Cameron, 2009a; see also 2009b; 2010a; 2011a). In a key speech on the theme, Cameron offers some symptoms of this brokenness:

So I think it is time to be honest about what has been happening to our country. There has always been violence. There has always been evil. But there is something about the frequency of these crimes - the depravity of these crimes, that betrays a deep and fundamental problem in Britain today. As I have argued for many years now, these

\footnotetext{
${ }^{2}$ It is true, however, that Cameron is referring to the Big Society much less frequently in 2012. A keynote speech on welfare in June (2012c) saw no mention, focusing instead on a 'responsible society'. It is unclear at the time of writing whether this is a temporary lull before one of the flagship policies periodic re-launches.

${ }^{3}$ For example, the 'pro-social society' in 2005 (Cameron, 2005; see also Cameron, 2007a), the'opportunity society' in 2006 (2006b) and the 'revolution in responsibility' (2007a).
} 
acts of murder and abuse are just the most violent and horrific expressions of what I have called the broken society.... Something is broken. Society is broken. (Cameron, 2010b)

Along with youth murders, more prosaic evidence of this breakdown is also noted, from hoax calls and physical threats to the fire service, the abuse of disabled people on the streets, drug addiction and suicide to the 'grim grind of hopelessness' experienced by the long-term unemployed. Unsurprisingly perhaps, after the urban riots across the UK in August 2011, Cameron (2011d) signalled that such criminality was a ‘wake-up call for our country’ and its 'broken society'.

The prescription for repairing this situation is the 'big society'. As the Conservative manifesto for the 2010 election put it 'Our society is broken, but together we can mend it: we can build the Big Society' (Conservative Party, 2010b, p. 35). And what Cameron (2011a) calls the 'key' to the Big Society, 'the one word at the heart of all this' is responsibility. The cause of the breakdown in society identified throughout Cameron's leadership is the need for more 'social responsibility' (Cameron, 2006b). Social responsibility is defined as 'the attitude, decisions and daily actions of every single person and every single organisation in society... the good society is a responsible society... What builds society, what encourages civility, is people taking responsibility. Putting each other before themselves' (Cameron, 2007a). As we explain below, both the NCS and the Community Resilience programme aim to enable and build this social responsibility for one's own conduct and that of one's community.

But why has social responsibility lapsed? The key analytical move made by Cameron's Conservatives (and that upon which their policy agenda relies entirely) has been to blame the crisis and breakdown on too much state involvement in the life of communities, i.e. 'big government'. This produces the deceptively simple dichotomy of big government and big society - with one being the source of everything identified as bad; the other as the source of everything good. Labour are thus accused of wanting to solve society's ills through more government and not seeing that '[i]t is more government that got us into this mess' (Cameron, 2009a) because 'big government has helped atomise our society' (Cameron, 2009b). The claim is that people have come to rely upon government and have begun to turn to government first for a solution to social problems, rather than their families, neighbourhoods 
and communities - i.e. society. Such 'big government' has led to a 'steady erosion of responsibility’ (Cameron, 2009a).

The paradox at the heart of big government is that by taking power and responsibility away from the individual, it has only served to individuate them. What is seen in principle as an act of social solidarity, has in practice led to the greatest atomisation of our society. The once natural bonds that existed between people - of duty and responsibility - have been replaced with the synthetic bonds of the state - regulation and bureaucracy (Cameron, 2009b).

The fundamental notion behind the Big Society then is to foster greater social responsibility in individuals, families, neighbourhoods, communities and, ultimately, the nation by making 'a big advance for people power' (Cameron, 2010d). The social responsibility that is called for ranges across four basic types identified in the 2010 election manifesto (Conservative Party, 2010b, p. vii), and elsewhere (Cameron 2006b; 2008; Conservative Party, 2010a, p. 1) as: personal, professional, civic and corporate responsibility. We are being asked to take more responsibility for our own family and friends, our own industry and workplace, our own community and neighbourhood, and for our employees and environment. Cameron (2007a) invokes John F. Kennedy in claiming that 'the big question is not what will government do, but what will society do?'

This foundational dichotomy of state vs. society and its affect on responsibility allows Cameron's Conservatives to hold on to Thatcher's legacy of opposing and rolling back the state, while tweaking it through their use of society in direct opposition. ${ }^{4}$ This gives us perhaps the most frequently used, if slightly awkward, aphorism of Cameron's leadership: the claim that 'there is such a thing as society - it's just not the same thing as the state' (Cameron, 2005; see also 2006b; 2007a; 2009a; Conservative Party, 2006, p. 1; 2010b, p. vii). Cameron has managed to build on the broad cross-party support which elected him as leader (see Heppell and Hill, 2009), keeping Thatcherites onside while blending elements of Willetts civic conservatism (Evans, 2010, pp. 331-2) with key insights from the right-wing leaderships of William Hague and Iain Duncan Smith (Blond, 2010, p. 32; Beech, 2009, pp.

\footnotetext{
${ }^{4}$ As one reviewer interestingly suggests, Cameron is also reappropriating and depoliticizing the notion of 'social solidarity', delegitimizing class solidarity and producing it as a way of coping with neoliberalism, rather than challenging it.
} 
28-9) and almost reproducing the Conservative One Nation group's recommendations from 1959 (see Seawright, 2010, pp. 168-9 regarding their document entitled The Responsible Society). Meanwhile, the undeniable influence of New Labour's Third Way (McAnulla, 2010) has been silently folded into this brand of 'progressive' Conservatism. Cameron’s Big Society has been presented less as a 'Red Tory' (Blond, 2010) idea, and more as a necessary development of Thatcherism based firmly in the opposition of state vs. society. The aim is thus not just rolling back the state, 'but rolling forward society’ (Cameron, 2007a).

The problem, of course, is that the state/society dichotomy does not work, and for two reasons: firstly, Cameron (2009b; 2010a) himself acknowledges that 'rolling forward society' requires state involvement - someone/something has to do the rolling. Secondly, as this article argues, because the changes that the Big Society intends to bring about do not imply less government but more management of people's conduct as individuals and a population, through communities, neighbourhoods and indeed self-government. Under the vision of a Big Society we are not to be less governed, but more efficiently and effectively so, by governing our own conduct and that of those around us in our families, neighbourhoods and workplaces.

While the latter problem will be the focus of most of the article, it is also important to outline the former. Despite the importance of the dichotomy to his policy framework, Cameron (2009b) acknowledges that ending big government does not produce a big society: 'it doesn’t follow that smaller government would automatically bring us together again... we must use the state to remake society'. Clearly government and society can be on the same side and not antagonists. Despite the rhetoric then, the issue is to produce a 'new role' for the state, a 'thoughtful reimagination' of its job (Cameron, 2009b). Cameron opposes this 'new role' to that of Labour's 'mechanistic view of the state - that it could and should command and control'. So the issue is not one of size at all, but one of function and method, the way government 'works' which should not be 'top-down, top-heavy, controlling' (Cameron, 2010d). The state he claims should not try to 'control' society 'directly through initiative, regulation and law' (2007a). Rather, it must be about producing the right conditions (Cameron, 2005), 'creating a framework of incentives that encourages people and organisations to behave responsibly’ (2007a). While Labour conceived the relationship between society and state as 'top-down, adult-to-child', Cameron (2009b) wants it to be one of adult to adult. So the state's role is reconceived as that of 'empowering and enabling individuals, families and communities to take control of their lives... Galvanising, catalysing, 
prompting, encouraging and agitating for community engagement and social renewal' (Cameron, 2009b; 2010a). Ironically, this is all language previously used by Labour's Stakeholder Society and Third Way. These earlier incarnations of a governmentality approach (see Rose, 2000) did not, however, involve public spending cuts; quite the reverse. ${ }^{5}$

Thus, this 'new' role for the state does not even imply less government - it has no necessary implications for quantity or size. Thus, the rhetoric of 'Big Society Not Big Government' both feeds from what it seeks to criticise in Labour's Third Way and fails to make sense on its own terms.

The new role for the state does, however, involve an increased number and range of actors. We argue that by engaging more and multifarious networks of actors - from social entrepreneurs to community activists and, ultimately, the population (Cameron, 2010d) what is proposed in the Big Society is far from being a matter of less government, but rather better, more efficient and effective management of people's behaviour and values. What is ultimately at stake here is perhaps the formation of ideally resilient, responsible citizens whose greater depoliticized productivity will help drive the country out of recession while mitigating structural defects of the UK economy. Nevertheless, the Big Society is not about reducing government but rolling forward governmentality. ${ }^{6}$ While Kerr, Byrne and Foster (2011: 201) have noted that 'arguably, shades of governmentality are reflected overtly in Cameron’s 'Big Society' rhetoric', they offer modest evidence and their tentative conclusion does little to demonstrate how thoroughgoing this governmentality agenda is, how deep it runs, or how wide-ranging its implications could be.

\section{GOVERNING INDIVIDUALS AND COMMUNITIES}

\footnotetext{
${ }^{5}$ A thorough comparison of the similarities between the Big Society and Labour's approach, especially regarding the 'enabling' role of the state, the stress on social responsibility and the role of the voluntary sector could begin with Blair 1996a; 1996b; Bevir 2000; Temple 2000. Sadly, it is beyond the scope of our current article.

${ }^{6}$ Foucault's understanding of 'power relations' evolved from power as discipline to power as government (what he calls 'governmentality' and which involves and maintains the disciplinary relation) - an interesting intermediate step in this development was 'biopower', that is a new technology of power over population: 'a set of mechanisms through which the basic biological features of the human subject became an object of political strategy' (Foucault, 2007: 1). We favour the use of a 'governmentality perspective' as a means of understanding how groups of individuals, communities and populations are controlled over using the concept of 'biopower' as it is the questions of 'how to govern oneself, how to be governed, by whom should we accept to be governed' (Foucault, 2007: 88) - i.e. the strategies and practices of governing - I that we are interested in over and above questions of how the regulation of the population happens using the biological fact that it is a species.
} 
The Big Society agenda has led to a range of policies, from parents running schools, communities operating local amenities and charities providing welfare services (see Cameron, 2009b) to setting up the four 'vanguard' areas of Liverpool, Eden in Cumbria, Sutton in London and Windsor and Maidenhead in Berkshire. ${ }^{7}$ Others include the Big Society Bank (Conservative Party, 2010a, pp. 2-4), National Centres for Community Organisation (Conservative Party, 2010a, p. 6), Social Enterprize Zones (Cameron, 2007b) and the Community First Scheme (Cameron, 2011b). However, it would be difficult for a list to be exhaustive because the Big Society concept runs throughout the government's policy agenda (Conservative Party, 2010a, p. 1; Cameron, 2010a). In the next two sections we will look at two policies that have emerged out of the Big Society agenda. These have been selected because while one is the long planned and much heralded flagship of the Big Society (the NCS), the other has opportunistically tacked the idea on to an existing approach to UK emergency planning (the Community Resilience programme). We outline the strategies and techniques of management and control that are used in these policies - i.e. the types of power relations they involve.

\section{The National Citizen Service (NCS): A Military Regime?}

Cameron chose to play on the 'National Service', a compulsory military service required by some governments, when labelling one of the flagship policies of the Big Society, the National Citizen Service (NCS). The 'NCS experience' (http://nationalcitizenservice.direct.gov.uk/) refers to a summer programme of outdoor activities set both at and away from home which teenagers, aged 15-16, can voluntarily take part in on completion of their GCSE's. ${ }^{8} 2011$ was the first of two pilot years - there were 11,000 spaces available that year, which has been be extended to 30,000 in 2012 and will be further extended to 90,000 by $2014 .{ }^{9}$ The National Service analogy is clearly intended to convey a sense of duty, service and 'common purpose' (guardian.co.uk, 2010), with the PM stating 'when you talk to people who did National Service, a lot of them say the thing was we did it together' (2011a - emphasis added). We argue that the NCS does indeed illustrate that we are in 'it' together - by showing that we are in government together: that is, we are governing ourselves, better, together. The goal of the NCS is to 'help to build a more

\footnotetext{
${ }^{7}$ Liverpool famously later withdrew from the vanguard programme because of government spending cuts that made its vanguard status unsustainable.

8 Further information on the NCS, including 'NCS details' and 'NCS Stories', is now available at http://nationalcitizenservice.direct.gov.uk/ (accessed 30 July 2012).

9 Statistics obtained from http://www.cabinetoffice.gov.uk/news/major-expansion-national-citizen-service-16year-olds (accessed 30 July 2012).
} 
cohesive, responsible and engaged society ... [through a] programme of activity and service' (Cabinet Office [CO], 2011e, p. 5 - emphasis added). Cameron (2009b) claims that it will produce 'socially responsible young people who can serve their community and get on with people from different backgrounds'. We argue that as well as perhaps producing 'socially responsible' young people, the NCS represents a series of governmental tactics that will produce better, more productive and communally-orientated citizens, even the 'ideal citizen'. This happens through more and better government, or governmentality, which operates via tactics that discipline and regulate behaviour, controlling through values such as responsibility and a sense of service.

Over seven to eight weeks, NCS participants go through five distinct phases of activity, which begin by introducing participants to their teams and mentors, involve spending time away from home/the local community and performing (typically outdoor) challenging activities such as rock climbing or kayaking. It ends with the participants designing a 'social action project', having approached and consulted groups and individuals in the local community. ${ }^{10}$ The weeks follow a rigorous, almost military, timetable nationwide though they do vary in nature according to the type of organisation the provider is. There are currently twelve lead providers for the 2011 pilots, which were determined following a competitive selection process. The providers are based in the nine areas throughout England, ${ }^{11}$ and include, for example: Catch 22 (offering 1, 515 places), Football League (Community) Ltd (800 places), The Challenge Network (3, 240 places) and The Prince's Trust (825 places). ${ }^{12}$ Some providers make a fairly comprehensive outline of the timetable of activities available on their websites, such as The Football League ${ }^{13}$ and The Field Studies Council which has set up an intensive environmental-themed NCS programme called Eco Challenge Xtra. ${ }^{14}$

\footnotetext{
${ }^{10}$ For a more detailed outline of the five phases see Cabinet Office, 2011e, p. 5.

${ }^{11}$ The nine areas are: Greater London, South East England, South West England, East of England, East Midlands, North East England, North West England, Yorkshire and Humberside, and West Midlands. A pilot scheme in Northern Ireland is being commissioned for the autumn of 2012 for 250 participants (see http://www.cabinetoffice.gov.uk/resource-library/national-citizen-service-northern-ireland, accessed 30 July 2012).

${ }^{12}$ The full list of providers is as follows: Bolton Lads and Girls Club, Catch 22, Connexions Cumbria Ltd, Field Studies Council, Football League (Community) Ltd, Lincolnshire and Rutland Education Business Partnership, Norwich City Community Sports Foundation, Safe in Tees Valley, The Challenge Network, The Prince's trust, $v$ - The National Young Volunteers' Service, Young Devon and South West Consortium.

${ }^{13}$ http://www.football-league.co.uk/fltrustnews/20110215/trust-selected-for-national-citizenservice_2293640_2294342 (accessed 29 June 2011).

${ }^{14} \mathrm{http}: / /$ www.eco-challenge-xtra.org/young-people/what\%E2\%80\%99s-really-involved.aspx (accessed 29 June 2011).
} 
The Challenge Network is one of a handful of providers that we contacted directly for more information on their schedule of activities and were able to offer greater detail on their NCS programme. Challenge bid for certain towns in London, the West Midlands and the North West of England. They visited every school in the area, approaching the head teachers in the first instance, attending Year 11 assemblies and following this up with workshops in an effort to recruit youngsters. During the first week of the programme, participants are divided into teams of twelve plus two mentors, who are expert staff. They undertake outdoor activities and, in their groups, the participants discuss how these apply to themselves, to their teams, and finally to their communities. 'It is very important that they make the link between the activity and the learning', explains Challenge’s Chief Executive, Craig Morley. ${ }^{15}$ In week two, as the teams are introduced to their local community, they must each choose an interest area, such as media, photography, drama or sport. They spend the morning being trained in that skill and in the afternoon they are taken to a local community group and may conduct a dialogue with that group, such as adults with severe learning disabilities. If interested in photography, the youngsters may take photographs of each other and talk about their life stories. The aim is to weave young people into the community (Morley interview: 2011)- to ensure they interact with people they would not normally interact with, such as the disabled, old people and the very young. Week three is about an explicit focus on the community. The youngsters are tasked with a project of their choice that will help their community (previous examples include road safety, underage drinking, and renovating local parks). To gather ideas, the participants may go door to door or stop people in shopping centres. The idea is pitched to a 'Dragon's Den style panel' who offer up to $£ 200$ to fund the project. Over the weeks of September, the participants put this project into action. By early October, there is a celebratory graduation ceremony, which typically takes place at a high profile venue and Challenge's Chief Executive explains that 'at that point, critically, we invite people to join The Challenge Society'.

The NCS programme of activities in each case illustrates a disciplinary formula used to manage the behaviour of individuals. Similar to Foucault's analysis of the construction of the body of the prisoner or the soldier in Discipline and Punish, the teenager becomes the object of certain practices that are directed at producing a body that can be made politically useful.

\footnotetext{
${ }^{15}$ Unless otherwise stated, all information on The Challenge Network taken from phone interview with Craig Morley, Chief Executive, The Challenge Network, 7 June 2011. Details available from http://www.thechallenge.org/about-us/people/founders/ (accessed 6 June 2011).
} 
Through a strictly regulated timetable of activities, the body of the teenager is thus 'subjected, used, transformed and improved' (Foucault, 1991, p. 136). The activities, from the physical activities to team-building sessions and discussions with mentors, are meticulous and minor techniques which together create a formula for controlling individuals. In this sense, the NCS reformulates the disciplinary framework of the army or the prison (see Foucault, 1991), without the necessity of spatial enclosure. The body of the teenager is then labelled as the 'ideal citizen' - one that is politically useful because it has been conditioned and regulated into a productive (because it will want to go out and work), communallyorientated (the work will be giving something back to the community) body.

This reworked disciplinary relation involves a strong element of pastoral power. Pastoral power, as explained by Foucault, refers to the 'power of care' (Foucault, 2007, p. 127) - it resembles the relation of a shepherd towards his flock, encompassing responsibility and beneficience. Moreover, it is both an individualising and collectivising power, at once concerned with each sheep of the flock and the flock as a whole. The teenager in the NCS model is surrounded by a range of experts that represent the pastorate: teachers, programme leaders, mentors, etc who guide and inform their behaviour. They 'keep watch' over the ‘flock' (Foucault, 2007, p. 127). The experts are characterised as such by virtue of possessing 'expert knowledge’ (Kennedy, 2005, pp. 17-8), which resembles a shared disciplinary sensibility and qualification. An excellent example of pastoral power is The Challenge Network's 'reflection sessions'. The evenings during week one involve 90 minute sessions where the mentor facilitates discussion on how to link the activities of the day to the general NCS/Big Society programme, i.e. character building. Morley identifies three common character traits that mentors focus on throughout the programme, calling these 'the thread' that runs through the whole 8-week programme: trust, responsibility and understanding. These three characteristics, which of course echo values intrinsic to the Big Society, are presented as values which should determine the behaviour of young people whilst on the NCS programme, and furthermore as values which they ought to aspire to once they have left and gone back to life in their communities.

The NCS thus concerns itself with the 'conduct of conduct'; that is, a concern with regulating the behaviour (conduct) of individuals (each teenager) and groups of individuals (all teenagers). Cameron himself has spoken of the aim of bettering government by controlling the behaviour of individuals claiming that the latest academic research has shown how 
government, 'by going with the grain of human nature, can better influence behaviour' (2009b - emphasis added). Managing behaviour shows government to be bettered, not lessened as Cameron claims - for it spreads the power relation throughout, and becomes more deeply ingrained within, the lowest levels of actors within the social body. Nikolas Rose (2000, p. 1399) has termed this a 'new politics of conduct' which functions via 'ethopolitics' - a type of power relation that 'works through the values, beliefs, and sentiments thought to underpin the techniques of responsible self-government and the management of one's obligation to others' (see also Rose, 2007). It is simply a different style of governing the conduct of teenagers - and one that is intended to continue into a 'postNCS' phase (CO, 2011e, p. 5), forming them into productive, well behaved, efficient (and docile) adult citizens.

Moreover, this new style of governing does not require a governor per se: the individual is at once the governor and the governed, regulating her own behaviour. Governmentality necessarily involves self-government. The pastoral relation helps illustrate how experts govern individuals in the NCS model but also how those young people will become experts in their own right - or 'lay experts' (Rose, 2007, p. 128) - and thereby become involved in their own government through the values prescribed to them by the Big Society (see also Author, 2011b). These are responsibility, trust and understanding according to one of the NCS providers, and responsibility, liberalism, freedom and empowerment according to Cameron (2010d). There is strong evocation of a 'sense of duty'. Young people become lay experts as they gain knowledge about the NCS, participate in its programmes and assume responsibility for their role in governing. The NCS website's 'Stories' section attests to this: as one participant so succinctly comments 'I think the programme will help me pursue my dreams of becoming a TV presenter and journalist and give something back to the community'. ${ }^{16}$

To expand, knowledge about the Big Society is gained by the young people initially through the pastoral relation with those that are considered experts in volunteer programmes, leadership activities, schooling, etc. But young people can also educate themselves and each other: they can access the NCS online via facebook, they can access documentation on the Big Society online and participate in the many and various Big Society online chat fora (such

\footnotetext{
${ }^{16}$ Ayesha Taylor-Camara, 16 from Woodford Green, http://nationalcitizenservice.direct.gov.uk/ (accessed 30 July 2012).
} 
as "The Big Society Network' ${ }^{17}$ ). Facebook is a good example of the self-educating, selfgoverning processes: the activity of searching, reading, writing, replying to and posting messages are all forms of technologies of the self - that is, techniques by which these young people govern themselves through prescribed modes of conduct. They will of course become educated through their participation in the NCS activities and volunteer programmes themselves. They are educating themselves and each other on how they ought to manage their behaviour within a prescribed framework of activity. As young people acquire knowledge and participate in the NCS processes, they will become responsible actors: it is key that this responsibility is assumed - it need not be conscious. The knowledgeable, active and responsible teenager is an 'ideal citizen': one that self-governs according to prescribed norms and values (see also Vaughan: 2000).

The NCS thus incorporates governmental strategies (a timetable of activities, a code of conduct) that discipline and manage behaviour, producing and normalising certain problematic identities: the (pastoral) 'expert' and the 'ideal citizen' (or lay expert). The creation of the 'ideal citizen' is troubling because it creates a third, oppositional category against which the ideal citizen can be readily recognised: the 'delinquent citizen', or 'thug'. This identity attaches itself even to those who do not take part in, or are not selected for, the NCS. The Government hopes that the NCS 'will become a valid part of public life and be open to every 16 year old' (CO, 2011e, p. 21) but there will inevitably be those who cannot or do not want to take part. ${ }^{18}$ This marginalises what we are calling the 'delinquent' category. The 'delinquent' is a politically useful category since it creates 'delinquency' - an abnormal, undesirable and illegal form of behaviour which the safe, virtuous, ideal society should guard against (Foucault, 1991, pp. 265-8). Delinquency characterises Cameron’s 'broken society' as the riots of August 2011 showed - and creates an unnatural, dangerous category of existence against which the PM was able to present his NCS programme as a necessity and an 'answer' (see Cameron, 2011d). The NCS thus at once produces the 'delinquent' and

\footnotetext{
${ }^{17}$ http://www.thebigsociety.co.uk/ accessed 29 June 2011.

${ }^{18}$ There is a concern not to allow the financial situation of young people to hinder participation - costs vary according to provider, for example the Football League puts the cost of the programme as between £50-100 (http://www.football-league.co.uk/fltrustnews/20110215/trust-selected-for-national-citizenservice_2293640_2294342 accessed 29 June 2011); Eco-Challenge Xtra states the cost is $£ 45$ (http://www.ecochallenge-xtra.org/young-people/what\%E2\%80\%99s-really-involved.aspx (accessed 29 June 2011) and The Challenge Network asks for £35 (Morley). Nonetheless, there are obviously not enough places to go around and while Morley stresses that Challenge has no set criteria, they do aim for a 'religious, ethnic and gender mix', measuring that mix 'on a weekly basis'. Others, such as Catch 22 appear to ask questions to gauge the level of the applicant's interest (http://www.catch-22.org.uk/NCS-register-your-interest accessed 29 June 2011). Note the 'Equality Duty' which binds all providers as per the Equality Act 2010 (see further CO, 2011e, p. 8).
} 
'delinquency', labels it as undesirable, and yet relies on its constant production in order to manage young people. The delinquent is both the inevitable failure of governmentality to manage conduct and a necessary part of that management - evidence that it cannot fail. It is governmentality in action: a reflexive form of government based on regulating behaviour according to values we are told we ought to aspire to in order to prevent a broken, delinquent society that can lead to violence, insecurity and a lack of care for the community. This is certainly not the opposite of big government - it is, rather, better, more diffuse government where individualss govern themselves and their communities.

\section{Community Resilience: Regulation Through Emergency}

The second example of the Big Society 'in action' that we examine here is the Community Resilience programme, the third phase of which was rolled out by the Cabinet Office in March 2011. As noted, in contrast to the flagship NCS, Community Resilience developed previous emergency planning techniques in the UK. The 2004 Civil Contingencies Act made it a statutory requirement for all key public services to build 'resilience' into their local governance infrastructure (Coaffee and Rogers, 2008, p. 104). Rather than reactive, this was part of an attempt to be proactive and pre-empt potential terrorist attacks and general 'emergencies'. Being 'prepared' for emergencies was seen as central to the ability of communities to 'bounce back' from disasters, itself a definition of resilience (Maguire and Hagan, 207: 16-17). While predominantly urban in nature and driven by central government, the notion of resilience demanded local government take the lead in response to crises, 'enabled by a far higher level of involvement from a multitude of stakeholders and business interests' (Coaffee, 2009, p. 263). It is therefore clear how the Big Society would map on to this agenda, with an emphasis on local experts, community actors, groups and businesses taking responsibility for their own security through resilience planning. The 'Strategic National Framework on Community Resilience' notes that the 'programme is part of the Government's “Big Society” commitment to reduce the barriers which prevent people from being able to help themselves and to become more resilient to shocks' (CO, 2011a, p. 3).

The Coalition Government's notion of community resilience went further, however, in extending this to rural, and indeed all communities. This was enacted primarily through the March 2011 Strategic Framework (CO, 2011a) already mentioned, as well as a range of other instructive documents produced with and for communities such as the 'Preparing for Emergencies: Guide for communities' (CO, 2011b) and the 'Community Emergency 
Planning Toolkit' (CO, 2011c). The ostensible aim of the programme is not conventional government, but to help existing communities to 'adapt in order to sustain an acceptable level of function, structure and identity’ (CO, 2011a, p. 4; from Edwards, 2009). Unlike the Civil Contingencies requirements, the Framework makes clear that this is 'not a mandated statement of expectations' but a 'proposed way forward' (CO, 2011a, p.5). Like all Big Society programmes, it is about 'motivating and incentivising participation' (CO, 2011a, p. 6), seeking not to 'dictate' but to 'support and enable' (2011a, p. 7). It is therefore a set of guidance which 'invite[s]' pre-existing communities to help themselves better survive and adapt in emergencies against all threats and hazards, such as floods and pandemics (CO, 2011a, p. 9).

This creates an emphasis on knowing the community - i.e. producing (labelling) individuals and groups of individuals so that they can be disciplined and managed. 'Community', much like 'delinquency', creates a category that can be confined, known, controlled and reproduced. It is clearly stated that the 'Community Resilience Programme is a long-term programme leading to cultural and behavioural change across the country’ (CO, 2011a, p. 15). Furthermore, the programme works to subdivide the community into different group and individual identities, placing them hierarchically in relation to each other such that they can be better managed, and, crucially, better manage themselves. As such, its aim is similar to Foucault's critique of the 'enclosure' of groups of individuals in barracks (soldiers), in schools (children) and in prisons (vagabonds), but without the spatial restriction: 'Its aim was to... know where and how to locate individuals, to set up useful communications... to be able at each moment to supervise the conduct of each individual, to assess it, to judge it, to calculate its qualities and merits. It was a procedure, therefore, aimed at knowing, mastering and using' (Foucault, 1991, p. 143).

The programme thus produces the resilience 'champions', 'experts', 'volunteers', 'resilient individuals' and finally, the 'vulnerable'. In a section identifying the key features of a resilient community, the Framework identifies the need for a 'champion', whose role is to communicate the 'benefits of community resilience to the wider community' (CO, 2011a, p. 15). The Guide for communities prefers the term 'community representative', whose function is to ensure that an emergency plan is created and coordinates the work of others towards that goal (CO, 2011b, p. 10). These individuals are therefore tasked with organisational roles, but also with disseminating the values and virtues of community resilience as they should be a 
trusted figure, who uses 'their energy and enthusiasm to motivate and encourage others to get involved and stay involved' (CO, 2011a, p. 15). They are charged with governing the ethos of community and its resilience.

In a semi-detached role, we also have the role of disaster management 'experts' and 'responders', such as the fire service, paramedics and flood protection specialists from the Environment Agency. They appear to be in, but not necessarily of, the community, and take a different role to the pastoral experts we saw in the NCS. They should 'work in partnership' with community resilience groups, offering 'encouragement' and advice on 'the biggest and most relevant risks', but are clearly separate and 'do not have a duty to facilitate or support community activity' (CO, 2011a, p. 14-5). Thus they are kept at a distance as part of official governmental emergency control. Indeed, in the Cabinet Office's definition of community resilience it is spoken of as the community acting to protect itself 'in a way that complements the response of the emergency services' (CO website - emphasis added).

A more central identity, created and guided by the champions and experts, is the 'volunteer'. A key commitment of the Big Society is for every adult in the country to become a member of an 'active neighbourhood group’ (Conservative Party, 2010a, p. 1; 2010b, 37-8), and the resilience programme enables this. The voluntary, rather than coerced, nature of such participation is stressed (CO, 2011a, p. 14), and the Toolkit notes that 'Volunteering is often spontaneous by nature' as people automatically help each other in times of need (CO, 2011c, p. 7). However, while avoiding compulsion, the Big Society's emphasis on social norms necessitates a degree of peer pressure. It is therefore suggested that 'as part of your planning, you could speak to individuals and groups in your community and ask them if they would be willing to volunteer in an emergency’ (CO, 2011c, p. 7). Though a light-touch form of behaviour management, more persuasion than coercion, being 'spoken to' by a group of community activists is nevertheless an exercise of power. And communities are directed towards advice on better 'managing groups of volunteers' by the Toolkit (CO, 2011c, p. 7).

Champions and volunteers then come to form the idealised 'resilient individual' (CO, 2011a, p. 15), those who the Framework refers to as 'having an informed understanding of the risks faced', the impacts of those risks, an ability to 'assess their proximity and vulnerability to those risks', and the 'motivation to act and be prepared' (CO, 2011a, p. 11). Resilient individuals share with the 'ideal citizen’ produced by the NCS the norms and values of social 
responsibility. The silent and never mentioned Other to this resilient individual is of course the 'reluctant' or 'recalcitrant individual', who fails to internalise the social norms of community and resilience. And like the delinquent, the recalcitrant individual demonstrates the failure and, conversely therefore, the success of the community governmentality through resilience. But the final identity created is that of the 'vulnerable'. The Toolkit advises that the community should make sure it is aware of this group, those in the community who 'may be vulnerable in a crisis' (CO, 2011c, p. 4). Special provision is suggested for people who have recently had an operation, those without transport, with limited mobility and those who might find it difficult to understand emergency information (CO, 2011c, p. 6). These are subjects without the capability to cope, and therefore require the help of truly resilient individuals, rather than the recalcitrant individual who, like the 'delinquent' in the NCS model, remains unmentioned.

But how can such vulnerable individuals be helped? Each group should be kept track of, documented and listed with the Community Emergency Plan. The 'Template' of such a plan offered by the Cabinet Office (see 2011d) even contains a section (p. 9) for keeping track of organisations to help the vulnerable. Thus another governmental tactic is the collection and dissemination of information and knowledge about the entire community - part of the first ‘step' towards community resilience (see CO, 2011c, p. 4). This information and data, despite appearing as 'mundane tools - surveys, reports, statistical methodologies, pamphlets, manuals... statistics, and so forth' (Inda, 2006, p. 6) are important not only because they make possible a knowledge of the community but also because they thereby make the communities visible, shaping them into forms that are calculable and able to be regulated (see further Author, 2011a). Forming the Community Emergency Plan, which involves identifying your community as well as its vulnerabilities, and then planning for how it will respond, cope and bounce back from tragic events, is about knowing one's community such that it can be better managed, controlled and directed even without an emergency actually occurring. This is furthered by the advice that communities should 'practice activating the plan to test how well it would work' and allowing the identification of 'any problems' with it (CO, 2011c, p. 12).

Drills and rehearsing one's plan then is a matter of disciplining a community to become more perfect, and thus more perfectly resilient. Segregating certain identities, promoting volunteerism, and collecting information and data on labelled groups (i.e. 'communities') within a population are techniques of spreading social norms, changing and directing its 
behaviour at a micro and macro-level. What is at stake in the formation of resilient communities and the exclusion of the recalcitrant is the maintenance and perpetuation of docility and efficient economic productivity that the NCS aims to produce, even after a disaster. Thus the resilience programme accepts the inevitability of emergencies but simply aims to 'adapt in order to sustain an acceptable level of function, structure and identity' (CO 2011a, 4). This does not involve 'big' conventional government but, like the rest of the Big Society, it involves strategies used for governing behaviour and dispersing a mentality of government, control and management throughout the social body. It is not about less or smaller government, but more efficient, effective and productive governing of selves, others and populations (as communities).

\section{CONCLUSION: GOVERNING BEHAVIOUR}

We have argued in this article that at the heart of the Big Society is the fostering of greater social responsibility in individuals, families, neighbourhoods, communities and, ultimately, the nation as a whole. The government's role is to create the environment where this is possible, but offer less by way of direct provision themselves. However, when we see government as a series of tactics for managing conduct, as a mentality, we can see this attempt to spread responsibility as one of disseminating and diffusing the exercise of power as government. It 'multipl[ies] the agencies of government' but also wrap them 'within new forms of control' (Osborne and Rose, 1999, p. 751). The new agencies created by the responsibilization of this governmentality are many and various, as we have seen in our case studies - from the experts of the NCS and the resilience 'Champions' to, crucially, teenagers and volunteers themselves.

The Big Society puts a major stress on individuals as agents, taking control of managing their own behaviour. Thus the 2010 Conservative Party (2010b) election manifesto was entitled: 'Invitation to Join the Government of Britain'. We are told to govern ourselves as well as others (2010b, p. 37). This is described as a form of empowerment, giving people 'the opportunity to take power' (Cameron, 2010a), a driving down of power to the level of the individual (Cameron, 2010d; 2010e). But this is not a conventional definition of power; it is not an ability to make others do what they would not otherwise choose. Rather, it is power defined as responsibility, a responsibility 'to do the right thing - by themselves and each 
other' (Cameron, 2011b). This is what the influential Philip Blond (2010, p. 35) advocates as a 'politics of virtue'. People may have been given greater agency as 'power and control' of themselves and their communities (Cameron, 2011a), but it is a heavily circumscribed form of agency: the power to cope with neoliberalism rather than challenge it; the power to do what is right, rather than what one wants. And unsurprisingly, it is part of the 'enabling' and 'galvanising' role of government to define what is right. This is government(ality) by values, or what Rose terms ethopower. The power 'we' are being given through the Big Society, then, does not include 'community activism' such as the rioting and looting seen in the UK's cities in August 2011, which Cameron described as 'sickening' (2011c). These activists are the essential 'delinquents' and 'recalcitrants'. They are not the active, responsible, 'ideal' subjects of self-government: the teenagers who spend their summer at the NCS, the perfectly resilient individuals, and further the parents who set up their own schools, the locals who run their own pub or post office, social entrepreneurs and charity workers (Cameron, 2009b).

However, this government by values extends far beyond the individual by seeking to socialise and change the behaviour of the population as a whole. Cameron notes that the strategies and techniques of governmentality will be aimed at three groups: the social entrepreneurs, the community activists and 'the population' itself (Cameron, 2009b). As he puts it, the 'big society demands mass engagement: a broad culture of responsibility, mutuality and obligation' (2009b; see also 2010a). The aim is for government to 'better influence social behaviour' by changing 'social norms'; with the 'right prompting, or "nudge”, government can effect a whole culture change' (Cameron, 2009b). Two specific social norms that are named are those of giving to charity and volunteering (Cameron, 2011b), but the culture change aimed at is obviously broader and includes all 'virtuous' behaviour. The explicit aim of the Big Society is thus to 'change social behaviour', to manage it better by encouraging the population to 'behave responsibly' (Cameron, 2007a). To what end is not always clear, but we have suggested behaviour change is oriented to producing (NCS) and maintaining (Community Resilience) more productive, communally-oriented, efficient, self-managing, depoliticized (and docile) individuals and groups.

Unsurprisingly perhaps, this attempt to change behaviour follows the same line as the Third Way, which 6, Fletcher-Morgan and Leyland (2011, pp. 427-8) have identified as the distinctive project of New Labour. But like the Third Way, produced in a growing economy and funded by greater public spending, this is not about less or smaller government, but more 
effective forms of government. In fact, this could be seen as an 'ideal' form of government, as Cameron (2010b) himself labels it, because 'it needn’t even involve the government doing anything' overtly (2009b) - individuals govern themselves through norms and values that they are led to aspire to. Cameron is therefore right to assert that the Big Society is 'not a cuts agenda' (2011b). It has nothing to do with less government and is not necessaryily linked to austerity but tries, rather, to diffuse the mentality of governing throughout society so we all govern ourselves and others around us more responsibly and virtuously. It is part of a more thoroughgoing liberalism in the double sense Foucault identified: a government informed by principles of political economy, but also 'a government which economizes on its own costs: a greater effort of technique aimed at accomplishing more through a lesser exertion of force and authority' (Gordon, 1991, p. 24). The liberal techniques of government produced by the Big Society - and demonstrated through the NCS and Community Resilience programme are thus smuggling in more government, greater social control, under a guise of empowerment, freedom and less government.

\section{REFERENCES}

Barron, A. (2005) 'Foucault and Law' in J. Penner et al (eds), Jurisprudence and Legal

Theory: Commentary and Materials. Oxford: Oxford University Press, pp. 955-1034

Beech, M. (2009) 'Cameron and Conservative Ideology', in S. Lee and M. Beech (eds), The Conservatives Under David Cameron: Built to Last? Basingstoke: Palgrave Macmillan, pp. 18-30.

Bevir, M. (2000) 'New Labour: a study in ideology', British Journal of Politics and International Relations, 2 (3), 277-301.

Blair, T. (1996a) New Britain: My Vision of a Young Country. London: Fourth Estate.

Blair, T. (1996b) ‘A stakeholder society’, Fabian Review, 103, 1-4.

Blond, P. (2010) Red Tory: How Left and Right Have Broken Britain and How We Can Fix It. London: Faber and Faber. 
Cabinet Office (2011a) Strategic National Framework on Community Resilience. March. London: Cabinet Office. Available from:

http://www.cabinetoffice.gov.uk/sites/default/files/resources/Strategic-National-Frameworkon-Community-Resilience_0.pdf (Accessed 30 May 2011).

Cabinet Office (2011b) Preparing for Emergencies: Guide for communities. March. London: Cabinet Office. Available from:

http://www.cabinetoffice.gov.uk/sites/default/files/resources/PFE-Guide-for-

Communities_0.pdf (Accessed 30 May 2011).

Cabinet Office (2011c) Community Emergency Plan Toolkit. March. London: Cabinet Office. Available from: http://www.cabinetoffice.gov.uk/sites/default/files/resources/CommunityEmergency-Plan-Toolkit.pdf (Accessed 30 May 2011)

Cabinet Office (2011d) Community Emergency Plan Template. March. London: Cabinet Office. Available from:

http://www.cabinetoffice.gov.uk/sites/default/files/resources/Community-Emergency-PlanTemplate.pdf (Accessed 5 June 2011).

Cabinet Office (2011e), Equality Impact Assessment, National Citizen Service Pilots: Making Government Work Better. April. Available from:

http://www.cabinetoffice.gov.uk/sites/default/files/resources/ncs-equality-impactassessment.pdf (accessed 29 June 2011).

Cabinet Office Community Resilience Website. Available from: http://www.cabinetoffice.gov.uk/content/community-resilience\#downloads (Accessed 5 June 2011).

Cameron, D. (2005) 'Building a pro-social society', 23 November. Available from: http://www.conservatives.com/news/speeches/2005/11/Cameron_Building_a_prosocial_Society.aspx (Accessed 8 July 2011). 
Cameron, D. (2006a) 'Chamberlain Lecture on communities', 14 July. Available from: http://www.conservatives.com/news/speeches/2006/07/David_Cameron_Chamberlain_Lectur e_on_Communities.aspx (Accessed 8 July 2011).

Cameron, D. (2006b) Party Conference Speech, 1 October. Available from: http://www.conservatives.com/News/Speeches/2006/10/Cameron_We_stand_for_social_resp onsibility.aspx (Accessed 5 July 2011).

Cameron, D. (2007a) 'Civility and Civil Progress', 23 April. Available from: http://www.conservatives.com/news/speeches/2007/04/Cameron_civility_and_civil_progress. aspx (Accessed 8 July 2011)

Cameron, D. (2007b) ‘A radical passion’, The Guardian, 7 August.

Cameron, D. (2008) Party Conference Speech, 1 October. Available from: http://www.conservatives.com/News/Speeches/2008/10/David_Cameron_Conference_Speec h_2008.aspx (Accessed 8 July 2011).

Cameron, D. (2009a) Party Conference Speech, 8 October. Available from: http://www.guardian.co.uk/politics/2009/oct/08/david-cameron-speech-in-full (Accessed 5 July 2011).

Cameron, D. (2009b) 'The Big Society’, Hugo Young Lecture, 10 November. Available from:

http://www.conservatives.com/News/Speeches/2009/11/David_Cameron_The_Big_Society.a spx. (Accessed 1 July 2011)

Cameron, D. (2010a) 'Our "Big Society” plan', 31 March. Available from: http://www.conservatives.com/News/Speeches/2010/03/David_Cameron_Our_Big_Society_ plan.aspx (Accessed 5 July 2011).

Cameron, D. (2010b) 'Let's mend our broken society', 27 April. Available from: http://www.conservatives.com/News/Speeches/2010/04/David_Cameron_Lets_mend_our_br oken_society.aspx (Accessed 8 July 2011). 
Cameron, D. (2010c) Speech at Big Society Launch, 18 May. Available from: http://www.number10.gov.uk/news/speeches-and-transcripts/2010/05/pm-and-deputy-pmsspeeches-at-big-society-launch-50283 (Accessed 5 July 2011).

Cameron, D. (2010d) Big Society Speech, 19 July. Available from: http://www.number10.gov.uk/news/speeches-and-transcripts/2010/07/big-society-speech$\underline{53572}$ (Accessed 5 July 2011).

Cameron, D. (2010e) 'Together in the National Interest', Party Conference Speech, 6 October. Available from: http://www.conservatives.com/News/Speeches/2010/10/David_Cameron_Together_in_the_N ational_Interest.aspx (Accessed 5 July 2011).

Cameron, D. (2011a), Speech on Big Society, 14 February. Available from: http://www.number10.gov.uk/news/speeches-and-transcripts/2011/02/pms-speech-on-bigsociety-60563 (Accessed 5 July 2011).

Cameron, D. (2011b), Speech on the Big Society, 23 May. Available from: http://www.newstatesman.com/blogs/the-staggers/2011/05/society-government-public (Accessed 5 July 2011).

Cameron, D. (2011c), Statement on restoring order to cities, 9 August. Available from: http://www.number10.gov.uk/news/pm-statement-on-restoring-order/ (Accessed 22 August 2011).

Cameron, D. (2011d), Speech on the fightback after the riots, 15 August. Available from: http://www.number10.gov.uk/news/pms-speech-on-the-fightback-after-the-riots/ (Accessed 22 August 2011).

Cameron, D. (2012a), Business in the Community Speech, 23 February. Available from: http://www.number10.gov.uk/news/business-in-the-community/ (Accessed 25 July 2012). 
Cameron, D. (2012b), Press conference launching Big Society Capital at the London Stock Exchange, 4 April. Available from; http://www.number10.gov.uk/news/transcript-pressconference-launching-big-society-capital-at-the-london-stock-exchange/ (Accessed 25 July 2012).

Cameron, D. (2012c), Welfare speech, 25 June. Available from: http://www.number10.gov.uk/news/welfare-speech/ (Accessed 25 July 2012).

Clegg, N. (2010a) Speech at Big Society Launch, 18 May. Available from: http://www.number10.gov.uk/news/speeches-and-transcripts/2010/05/pm-and-deputy-pmsspeeches-at-big-society-launch-50283 (Accessed 5 July 2011).

Clegg, N. (2010) 'Foreword', in HM Government, Decentralisation and the Localism Bill: an essential guide. London: Department for Communities and Local Government.

Coaffee, J. (2009) Terrorism, Risk and the Global City: Towards Urban Resilience. Aldershot: Ashgate.

Coaffee, J. and Rogers, P. (2008) 'Rebordering the City for New Security Challenges: Counter-terrorism to Community Resilience', Space and Polity, 12 (1), 101-118.

Conservative Party (2006), Built to Last: The Aims and Values of the Conservative Party. London: Conservative Party. Available from:

http://www.conservatives.com/pdf/builttolast.pdf (Accessed 5 July 2011).

Conservative Party (2010a) Building a Big Society. London: Conservative Party. Available from:

http://www.conservatives.com/News/News_stories/2010/03/Plans_announced_to_help_build _a_Big_Society.aspx . (Accessed 8 July 2011).

Conservative Party (2010b), Invitation to Join the Government of Britain: The Conservative Manifesto 2010. London: Conservative Party. Available from:

http://www.conservatives.com/Policy/Manifesto.aspx (Accessed 8 July 2011). 
Edwards, C. (2009) Resilient Nation. London: Demos.

Evans, S. (2010) “"Mother’s Boy”: David Cameron and Margaret Thatcher’, British Journal of Politics and International Relations, 12 (3), 325-343.

Foucault, M. (2007) Security, Territory, Population: Lectures At the Collège de France, 1977-1978, M. Senellart (ed.). New York: Palgrave Macmillan.

Foucault, M. (2002) 'The Subject and Power', in J. Faubion (ed.), Power: Volume 3: Essential Works of Foucault 1954-1984. London: Penguin, pp. 326-348.

Foucault, M. (1991) Discipline and Punish: The Birth of the Prison. London: Penguin Books.

Gordon, C. (1991) ‘Governmental Rationality: An Introduction’, in G. Burchell, C. Gordon, and P. Miller (eds), The Foucault Effect: Studies in Governmentality. London: Harvester/Wheatsheaf, pp. 1-51.

Guardian.co.uk (2010), 'Michael Caine endorses Conservatives’ national service plan’ 8 April. Available from:http://www.guardian.co.uk/politics/video/2010/apr/08/michael-cainedavid-cameron?INTCMP=ILCNETTXT3487

Heppell, T and Hill, M. (2009) 'Transcending Thatcherism? Ideology and the Conservative Party Leadership Mandate of David Cameron', The Political Quarterly, 80 (3), 388-399.

Inda, J. X. (2006) Targeting Immigrants: Government, Technology, and Ethics. Blackwell: Oxford.

Kennedy, D. (2005) 'Challenging Expert Rule: The Politics of Global Governance’, Sydney Law Review, 27, 1-24.

Kerr, P., Byrne, C. and Foster, E. (2011) ‘Theorising Cameronism’, Political Studies Review, 9 (2), 193-207. 
Maguire, B and Hagan, P. (2007) 'Disasters and communities: understanding social resilience', The Australian Journal of Emergency Management, 22:2, 16-20.

McAnulla, S. (2010) 'Heirs to Blair's Third Way? David Cameron's Triangulating Conservatism’, British Politics, 5 (3), 286-314.

Morley, C. Chief Executive, The Challenge Network, Interview with Author by Phone, 7 June 2011.

Osborne, G. (2009a) 'Progressive reform in an age of austerity', 11 August. Available from: http://www.conservatives.com/News/Speeches/2009/08/George_Osborne_Progressive_refor m_in_an_age_of_austerity.aspx (Accessed 5 July 2011).

Osborne, G. (2009b) 'We will lead the economy out of crisis', 6 October. Available from: http://www.conservatives.com/News/Speeches/2009/10/George_Osborne_We_will_lead_the _economy_out_of_crisis.aspx (Accessed 5 July 2011).

Osborne, G. (2010) 'Unleashing the forces of enterprise', 27 February. Available from: http://www.conservatives.com/News/Speeches/2010/02/George_Osborne_Unleashing the_fo rces_of_enterprise.aspx (Accessed 5 July 2011).

Osborne, T. and Rose, N. (1999) 'Governing cities: notes on the spatialisation of virtue', Environment and Planning D: Society and Space, 17 (6), 737-760.

Rose, N. (2007) The Politics of Life Itself: Biomedicine, Power, and Subjectivity in the Twenty-First Century. Princeton: Princeton University Press.

Rose, N. (2000) 'Community, Citizenship, and the Third Way', American Behavioural Scientist, 43 (9), 1395-1411.

Seawright, D. (2010) The British Conservative Party and One Nation Politics. New York and London: Continuum.

Smith, M. J. (2010) 'From Big Government to Big Society: Changing the State-Society Balance', Parliamentary Affairs, 63 (4), 818-833. 
Social Justice Policy Group (2006), Breakdown Britain: Interim report on the state of the nation (London: The Centre for Social Justice).

Stratton, A. (2010) 'Children's Minister: what is big society - Ann Widdecombe?', The Guardian, 10 November.

Temple, M. (2000) 'New Labour’s Third Way: pragmatism and governance', British Journal of Politics and International Relations, 2 (3), 302-325.

6, P., Fletcher-Morgan, C. and Leyland K. (2010) 'Making People More Responsible: The Blair Governments’ Programme for Changing Citizens’ Behaviour’, Political Studies, 58 (3), 427-449.

Vaughan, B. (2000) 'The Government of Youth: Disorder And Dependence?', Social and Legal Studies, 9 (3) 347-366. 